however, on West German political science after 1945 is often exaggerated.

3. Therefore, from a broader point of view political science marked an early turning point in the history of German social sciences; it took nearly a generation of scientists in history or law schools to let the mainstream give up the idea of a German 'Sonderweg' and join the western discussion.

4. For a short history of West German political science, see Kastendiek (1987).

5. Roeder is professor of theory and state and law and acting director of the Institute of Theory of State and Law at the Academy of Sciences of the GDR. He is President of the Nationalkomittee and member of the Executive Committee of IPSA.

6. See: Politisches Wörterbuch, New Edition 1988. East Berlin: Dietz Verlag, 157 pp.

7. For a description of the atmosphere in the universities and institutes in these days, see Zittern und Klappern. An den DDRUniversitäten fürchten Professoren um ihre Stellen. In: Der Spiegel 22, May 28, pp. 82-85.

8. Resolution, January 18, 1990. Department of Political Science, Free University Berlin.

9. Leipziger Professoren vermissen geistige Erneuerung in Der Karl-MarxUniversität. In Frankfurter Allgemeine Zeitung, june 5, 1990.

10. About former SED scientists at the Humboldt University, see Weiter auf antikapitalistischem Weg-die PDS Gesellschaftswissenschaftler an der Berliner Humboldt Universität geben nicht auf. In: Frankfurter Allgemeine Zeitung, July 13, 1990. Deutschdeutscher Streit um Uni-Stellen. In: Die Tageszeitung (Berlin edition), July 17, 1990.

11. See: Kein Interesse an West Professoren. In: Die Tageszeitung (Berlin edition), May 18, 1990.

12. Harro Kendschek works in a teachers' training college in Leipzig.
13. For a survey of the various activities in Berlin, see Massing (1990)

14. Hans Zacher, president of the MaxPlanck-Institute. In: Die Welt, June 22, 1990.

15. Much of this development was the result of the work of Peter Christian Ludz (see Buchstein 1989). For an excellent review of forty years of West German GDR research in political science, see Thomas (1990).

16. See: Die DDR-Forschung wird ihren Gegenstand überleben. In: Die Tageszeitung (Berlin edition), June 12, 1990.

\section{References}

Anweiler, Oskar. 1989. "Bildung und Wissenschaft in der DDR," in Deutschland Handbuch, ed. Werner Weidenfeld and Hartmut Zimmermann. München: Carl Hanser Verlag, pp. 370-388.

Arendt, Hannah. 1950. "The Aftermath of Nazi-Rule. Report from Germany.' Com mentary 14: 342-353.

Buchstein, Hubertus. 1989. "Ideologie und Empire. Der Versuch einer Rekonstruktion des intellektuellen Profils von P. C. Ludz," in Politik und Gesellschaft in sozialistischen Ländern, ed. Ralf Rytlewski. Opladen: Westdeutscher Verlag, pp. 121-147.

Buchstein, Hubertus and Gerhard Göhler. 1986. 'In der Kontinuität einer 'braunen' Politikwissenschaft?' Politische Vierteljahresschrift 27: 330-340.

Buchstein, Hubertus and Gerhard Göhler. 1990. Die Wiederbegründung der Politikwissenschaft in Berlin nach 1945. (Forthcoming).

Fischer, Alexander and Günther Heydemann eds. Geschichtswissenschaft in der DDR. Band 1. Berlin: Duncker und Humblot.

Hager, Kurt. 1976. Der IX. Parteitag und die Gesellschaftswissenschaften. East Berlin:
Staatsverlag der DDR.

Heuer, Jens Uwe. 1989. Marxismus und Demokratie. East Berlin: Staatsverlag der DDR.

Heuer, Jens Uwe. 1990. Marxismus und Demokratie, 2 nd ed. with a new preface. Baden-Baden: Nomos.

Kastendiek, Hans. 1987. “'Political Science and Political Development in (West) Germany." International Political Science Review 8: 25-40.

Lötsch, Manfred. 1990. "Stand und Perspektiven der DDR-Soziologie." DeutschlandArchiv 5: 552-555.

Ludz, Peter Christian, ed. 1964. Studien und Materialien zur Soziologie der DDR. Köln and Opladen: Westdeutscher Verlag.

Massing, Peter. 1990. "Lehrer drücken die Schulbank. Politikwissenschaftliche Fortund Weiterbildungsmöglichkeiten an der FU für DDR-Gesellschaftskundelehrer." FU-Info 6: 8-10.

Roeder, Karl-Heinz. 1989. "Political Science in the German Democratic Republic." PS Political Science and Politics, September: 753-758.

Thomas, Rüdiger. 1990. "Von der DDRForschung zur komparativen DeutschlandForschung." Zeitschrift für Parlamentsfragen 21: 126-137.

\section{About the Authors}

Hubertus Buchstein, born 1959, is assistant professor in political theory, and Gerhard Göhler, born 1941, is full professor in political theory at the Department for Political Science, Free University of Berlin. Göhler is a member of the board of the "Deutsche Vereinigung für Politische Wissenschaft" (DVPW, German Political Science Association) and speaker of the Political Theory Section of DVPW.

\title{
Soviets Sanction Gender Studies
}

\author{
Catherine E. Rudder, American Political Science Association
}

\section{The USSR Academy of Sciences has established a Center for Gender Studies within the Institute for Socio- Economic Studies of Population. Gender studies is an entirely new field in the USSR. In fact, until recently there was no word in the Russian language corresponding to the English word of "gender." As a consequence, a Russian neologism "gender" (pronounced with a hard " $g$ ") has been created to connote this social concept.}

Dr. Anastasia Posadskaya, Deputy Director of the new center, visited the United States in June and met with me in APSA's Washington office to describe the work of the gender studies center. Dr. Posadskaya explained that the establishment of her center would have been impossible prior to Perestroika when the fiction that Soviet men and women were treated equally was officially maintained. Fundamental to promoting that fabrication was the Communist Party's Women's Committee, which still exists in the precarious status experienced by many party nomenclatura today.

While the new center has apparently not been accepted with open arms by many of the old guard in the Soviet Academy, it has garnered some important resources with which to carry on its research, including five professional staff lines, some space, and telephones. While she was in the U.S., Posadskaya additionally obtained a fax machine donated by the Soros Foundation so that communication can be facilitated between the center and colleagues around the world. Still, the center is in need of such basic materials as books for its meager but growing library and a personal computer. Much of the professional staff's time is squandered 
on repetitive, menial tasks that an inexpensive computer would obviate.

The work performed by the center's scholars is varied and reflects the academic background of the five researchers. One is a philosopher and working on assumptions that underlie language. The emphasis of the other four is on social science in the relatively rigorous sense of requiring systematically gathered empirical data to support assertions. The center is making use of newly available public opinion data for secondary analysis. Thus far the center has conducted two sociological surveys on women's issues and problems.

In addition to conducting research, the center has established a data bank on gender problems and the status of women in the USSR and is collecting books on gender-related topics. There is a scarcity of such data and volumes in the USSR. The center has created its own system of social indicators to monitor the situation in the USSR.

As an official organ of the Soviet Academy of Sciences, the center also prepares recommendations and legislation to improve the status of women in the Soviet Union. Posadskaya reported that while higher authorities do not necessarily take the recommendations of the center, they are now permitting women's rights concerns to be expressed where no voice had been heard previously.
Posadskaya's approach as she presses ideas on behalf of women seems to be cautious and research-based, yet persistent. Based on the resources the center has garnered from the government, her center seems to be making some inroads.

Posadskaya expressed a desire to establish ties with corresponding research centers abroad, especially in the United States. Anyone interested in the work of the center or in making contact with Posadskaya can write her at: Center for Gender Studies, Institute for Socio-Economic Studies of Population, USSR Academy of Sciences, Krsikova, 27, Moscow II72I8, USSR (telephone: I25-73-02). 